\title{
Isokinetic performance, functionality, and pain level before and after lumbar and pelvic estabilization exercise in individuals with chronic low back pain
}

\author{
Desempenho isocinético, funcionalidade e dor antes \\ e depois de exercícios de estabilização lombopélvica \\ em indivíduos com lombalgia crônica
}

\author{
Jarbas Melo Filho $^{[\mathrm{a}]}$; Fernanda Maria Cercal Eduardo ${ }^{[\mathrm{a}]}$; Auristela Duarte de Lima Moser $^{[\mathrm{b}]}$ \\ [a] MSc, Pontifícia Universidade Católica do Paraná, Programa de Pós-Graduação em Tecnologia em Saúde, Curitiba, PR - \\ Brazil, e-mail: jarbasmf@hotmail.com; fer_eduardo@hotmail.com \\ [b] PhD, professor, Pontifícia Universidade Católica do Paraná, Programa de Pós-Graduação em Tecnologia em Saúde, \\ Curitiba, PR - Brazil, e-mail: auristela.lima@gmail.com
}

\begin{abstract}
Introduction: Chronic low back pain with a mechanical and degenerative origin is among the most common symptoms experienced by people all over the world. Objective: To analyze the effects of a protocol for lumbar and pelvic segmental stabilization with regard to isokinetic variables, functionality, and pain in patients with low back pain. Materials and methods: The sample consisted of 21 subjects, 8 female and 13 male, with a mean age of $42.6 \pm 12.5$ years. We used tests for mobility (modified Schober index), flexibility (finger-floor distance), functionality (Roland-Morris questionnaire), pain (Visual Analog Scale of Pain), and the isokinetic variables torque peak, work, flexors/extensors ratio before and after application of a protocol for segmental stabilization in subjects with chronic low back pain with a mechanical and degenerative origin. This protocol was used for two months, being applied twice a week. The data were statistically tested by means of the software Statistica, version 8.0. Results: There were significant improvements for the variables flexibility $(\mathrm{p}=0.014)$, functionality $(p<0.001)$, pain level $(p<0.001)$, torque peak flexion $(p=0.008)$, torque peak range $(p<0.001)$, torque flexion $(p=0.001)$, torque range $(p<0.001)$, and flexors/extensors ratio $(p=0.001)$. Conclusion: Even with the improved levels of trunk muscles strength, both flexors and extensors, it was not possible to rebalance the segment according to data available in the literature. It is believed that there is a need for a protocol with a
\end{abstract}


longer application period, maintaining the recruitment of extensor muscles. Regarding mobility of the lumbar segment, the protocol showed no significant differences in post-treatment $(p=0.520)$. This may be attributed to improved muscle control, providing the increased passive stiffness required to promote stability.

Keywords: Spine. Low back pain. Flexibility. Muscle strength dynamometer.

\section{Resumo}

Introdução: A dor lombar crônica de origem mecânico-degenerativa é um dos sintomas de maior incidência na população mundial, independente do fator causal, e tem estreita relação com a instabilidade do segmento lombar da coluna vertebral. Objetivos: Analisar os efeitos de um protocolo de estabilização segmentar lombo- pélvica nas variáveis isocinéticas, funcionalidade e dor em indivíduos com lombalgia. Materiais e métodos: A amostra foi composta por 21 sujeitos, 8 do gênero feminino e 13 masculino, com idade média de 42,6 \pm 12,5 anos. Foram utilizados testes de mobilidade (Índice de Shober Modificado), flexibilidade (Distância mão-chão), funcionalidade (Questionário Roland-Morris), dor (EVA) e variáveis isocinéticas Pico de torque, Trabalho e Relação F/E antes e após aplicação de um protocolo de Estabilização Segmentar em sujeitos com lombalgia crônica mecânico-degenerativa. O protocolo teve duração de dois meses, sendo aplicado duas vezes por semana. Os dados foram testados estatisticamente através do programa computacional Statistica v.8.0. Resultados: Obteve-se melhoras significativas para as variáveis, flexibilidade $(p=0,014)$, funcionalidade $(p<0,001)$, nível de dor $(p<0,001)$, PT Flexão $(p=0,008)$, PT Extensão $(p<0,001)$, T Flexão $(p=0,001)$, T Extensão $(p<0,001)$ e Relação $F / E(p=0,001)$. Conclusão: Mesmo com a melhora dos níveis de força dos músculos do tronco flexores e, sobretudo, extensores -, não foi possível reequilibrar o segmento segundo os dados da literatura. Acredita-se que um protocolo de maior duração com a manutenção do recrutamento dos músculos extensores torna-se necessário. Em relação à mobilidade do segmento lombar, o protocolo não apresentou diferenças significativas no pós-tratamento $(p=0,520)$. Isto pode ser atribuído ao melhor controle muscular desenvolvido, proporcionando aumento da rigidez passiva necessária para promoção da estabilidade.

Palavras-chave: Coluna vertebral. Lombalgia. Flexibilidade. Dinamômetro de força muscular.

\section{Introduction}

Nowadays, chronic low back pain with a mechanical and degenerative origin is among the most common symptoms experienced by people all over the world, regardless of the causal factor, and it is closely related to instability in the lumbar spine segment. Scientific evidence indicates that the treatment focus has been on exercise methods for segmental stabilization. This is the only way to provide patients with lumbar and pelvic dysfunctions with full recovery of the deep muscles functioning, something which stabilizes the structures concerned and, as a consequence, relieves pain and improves functionality and quality of life.

Stability of the lumbar and pelvic complex is defined as the ability to keep balance and firmness in their structures while performing body movements, and the improvement of segmental stability and trunk neuromuscular control can provide a solid foundation not only for the segment, but also for the whole body, as it prepares the body to deal with external disturbances, such as traction, torsion, and shear, which can cause injuries to the segment or other body parts $(1,2,3,4)$.

Lumbar and pelvic segmental stabilization exercises advocate for the evolution of deep muscle contractions, especially the transverse abdominal and the lumbar multifidus muscles, in addition to preservation of the pelvis in a neutral position and muscle work at the pelvic floor $(5,6,7,8)$.

The ways for assessing lumbar and pelvic stability range from simple palpation of local muscles and isometric endurance tests to use of equipment such as electromyograph, ultrasound imaging device, and isokinetic dynamometer $(9,10,11,12,13)$.

Isokinetic dynamometry for trunk assessment determines the muscle torque of flexor and extensor 
groups, analyzing the agonist/antagonist balance for a better treatment planning and injury prevention, providing criteria for discharging the patient $(14,15)$.

Despite the proliferation of practices based on lumbar and pelvic stabilization, lumbar spine instability remains a controversial topic, and there is a lack of scientific evidence regarding the proper definition of the term and the assessment and intervention alternatives in these practices. This study aimed to analyze the effects of a protocol for lumbar and pelvic segmental stabilization in individuals with low back pain with regard to isokinetic variables, functionality, and pain.

\section{Materials and methods}

We conducted a quantitative prospective study in the Physical Therapy Clinic of the Pontifical Catholic University of Paraná (PUCPR). The initial sample consisted of 46 individuals with low back pain; 22 subjects were male and 24 were female.
The inclusion criteria were: low back pain with a mechanical and degenerative origin; lumbar pain for more than three months; lack of regular physical activity; age between 20 and 60 years. The exclusion criteria were: use of analgesic and/or anti-inflammatory medicines; osteopenia or osteoporosis; back surgery less than six months before; pregnancy; treatment for low back pain; and labor law litigation.

At the end of the survey, the sample was reduced to 21 subjects, 13 male and 8 female. Participants signed a free and informed consent term in order to be included into the study, after approval by the Research Ethics Committee, under the Opinion 6,452/2012.

We evaluated: lumbar segment mobility, using the Schober index $(16,17)$; posterior chain flexibility, using the finger-floor distance test $(18,19)$; functionality, using the Roland-Morris questionnaire (20); and pain, using the Visual Analog Scale of Pain (VASP) (21). For assessing muscle performance, we used the isokinetic dynamometer model Cybex ${ }^{\circledR} 7000$ trunk module in flexion $\left(50^{\circ}\right)$ and extension $\left(0^{\circ}\right)$ trunk movement (Figure 1), at the angular speed of $60^{\circ} / \mathrm{s}$.

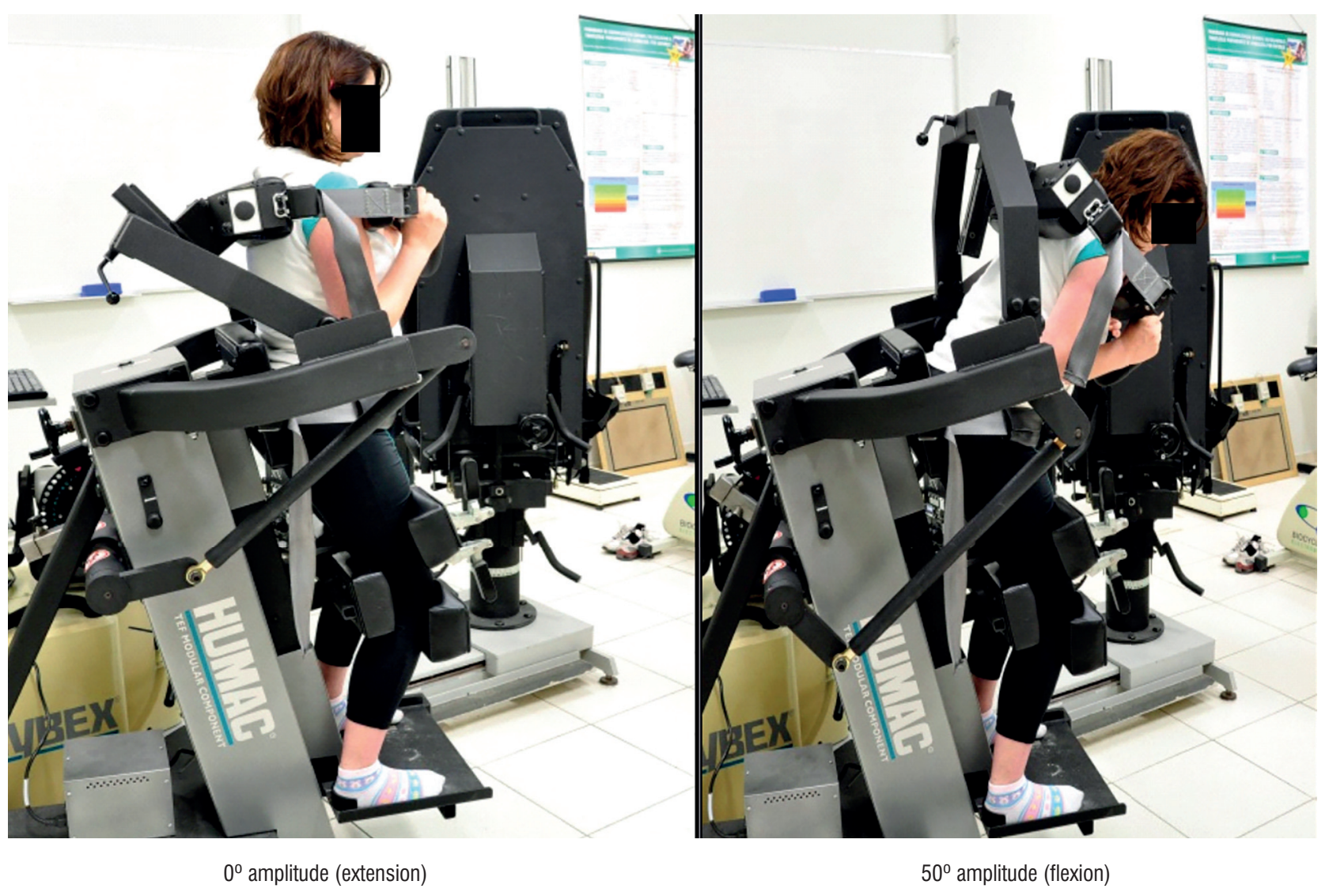

Figure 1 - Isokinetic test amplitude (side view)

Source: Research data. 
Five sub-maximum repetitions for familiarization and five maximum repetitions after 30 seconds of rest. The variables analyzed were torque peak (TP) in newton meter (Nm), work (W) in joules (J) and flexors/extensors (F/E) ratio in percentage (\%) (22, $23,24,25)$.

The exercise protocol (Table 1) was performed twice a week, totaling sixteen sessions.

At the end of each stage, hip and knee joint flexion and extension movements were performed, in order to relax for a minute.

For data analysis, we used the software Statistica, version 8.0. When comparing pre- post-treatment assessments, we used Student's t-test for paired samples or the non-parametric Wilcoxon test. P values < 0.05 were regarded as statistically significant.

\section{Results}

Among the 46 subjects, 5 underwent only the initial assessment and did not start treatment, 10 quit the program after the $3 \mathrm{rd}$ session, 5 quit after the $4^{\text {th }}$ week, 2 underwent spine surgery during treatment, and 3 did not attend the final assessment. The final sample consisted of 21 subjects, with a mean age of $42.6 \pm 12.5$ years.

Tables 2 and 3 present the descriptive statistics and $p$ values of statistical tests of the variables in this study.

All study variables, except mobility, showed a satisfactory performance.

\section{Discussion}

\section{Effects on Muscle Strength}

Another study (26), analyzing the same variables of this study, after trunk strengthening in subjects with low back pain with a mechanical origin, found out significant outcomes in two exercise programs for pain, mobility, flexibility, and trunk extensor strength, but not for flexors, unlike this study. The poor performance of flexors in this study may be attributed to a limitation of equipment (Cybex ${ }^{\circledR} 6000$ ), since it does not correct the gravity force, something which can be corrected by the researcher manually programming the machine.

This study followed the parameters indicated in that study (26), but adopted a different angular speed in the isokinetic test and the protocols, thus, it does not allow an absolute comparison.

We measured the initial imbalance between flexors and extensors, to the disadvantage of extensors, and even with the performance gain in both groups (higher in extensors), $(\mathrm{p}=0.001)$, extensor deficit persisted when compared to individuals with no pain (27).

An imbalance in trunk muscle strength may be a risk factor for low back pain, according to another study (28).

Although we did not use concentric exercises of trunk flexors, the outcomes showed a significant difference with regard to increased strength of these muscles ( $p=0.001)$, corroborating another study (27).

Furthermore, it has been reported (29) reported that an explanation for the high rate of recurrence in patients with low back pain may be due to the fact that these muscles do not recover volume, even after pain is reduced, compromising stability. Regarding the lumbar multifidus muscles, improvement after treatment was significant $(\mathrm{p}<0.001)$, increasing the flexors/extensors balance.

\section{Effects on Pain and Functionality}

Another study (30) compared general exercises to general exercises along with spinal stabilization in patients with low back pain, and it found out positive outcomes in both groups.

This study followed the parameters proposed in that research (30), as well as those from another one (31), for a treatment with lumbar stabilization with regard to the parameters intensity, length, and evolution of exercises, showing effectiveness in terms of pain and functionality.

This article corroborates another study (32), where the researchers observed the effects of stabilization in the short and medium terms with regard to pain and functional performance in individuals reporting positive effects after 4 weeks applying the technique, as well as a positive follow-up from 2 to 5 months.

A follow-up study (33) reports that recovery from inhibition of lumbar multifidus muscles associated to the first episode of low back pain does not occur immediately after resolution of pain, even when functional levels return to normal. If there is no recovery of muscle volume, a high proportion of patients can have a deficit in their ability to stabilize, despite the absence of pain. Therefore, protocols with a minimum length of eight weeks are more likely to keep the gains obtained. 


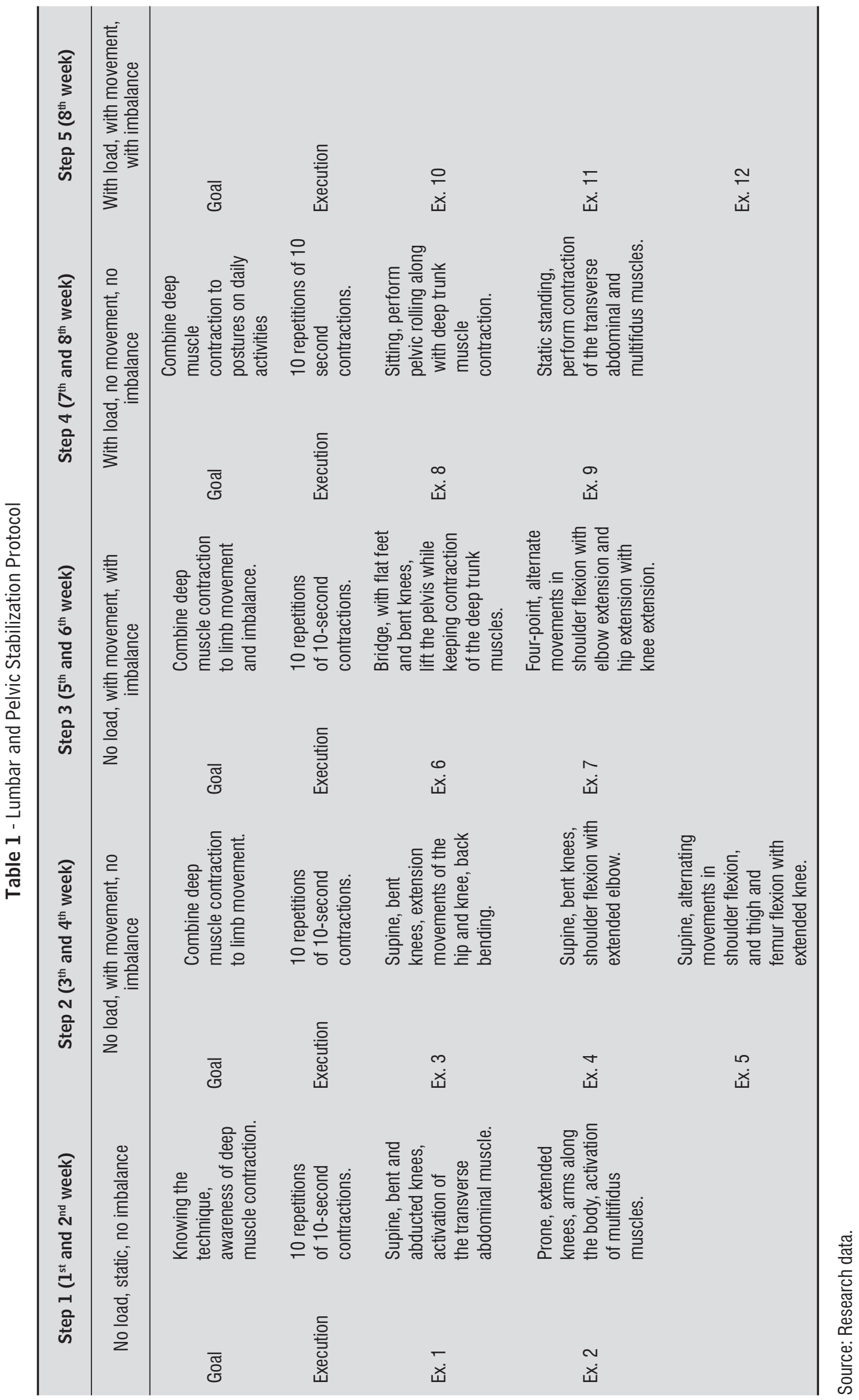


Melo Filho J, Eduardo FMC, Moser ADL.

Table 2 - Descriptive statistics of the variables mobility, flexibility, functionality, and pain level, and the p values of statistical tests

\begin{tabular}{|c|c|c|c|c|c|c|c|c|}
\hline Variable & Assessment & $\mathbf{N}$ & Mean & Median & Minimum & Maximum & $\begin{array}{l}\text { Standard } \\
\text { deviation }\end{array}$ & $\begin{array}{l}\text { P } \\
\text { value* } \\
\text { (pre- x } \\
\text { post-) }\end{array}$ \\
\hline \multirow{3}{*}{$\begin{array}{l}\text { MOBILITY } \\
\text { (Schober index) }\end{array}$} & Pre- & 21 & 14.8 & 15.0 & 13.0 & 18.0 & 1.2 & \multirow{3}{*}{0.520} \\
\hline & Post- & 21 & 15.0 & 15.0 & 13.0 & 17.0 & 1.0 & \\
\hline & $\begin{array}{l}\text { Diff (pre- } \\
\text { post-) }\end{array}$ & 21 & 0.2 & 0.0 & -2.0 & 2.0 & 1.2 & \\
\hline \multirow{3}{*}{$\begin{array}{l}\text { FLEXIBILITY } \\
\text { (finger-floor } \\
\text { distance) }\end{array}$} & Pre- & 21 & 17.8 & 16.0 & 0.0 & 39.0 & 11.0 & \multirow{3}{*}{0.014} \\
\hline & Post- & 21 & 13.6 & 13.0 & 0.0 & 35.0 & 9.5 & \\
\hline & $\begin{array}{l}\text { Diff (pre- } \\
\text { post-) }\end{array}$ & 21 & -4.1 & -5.0 & -18.0 & 13.0 & 7.1 & \\
\hline \multirow{3}{*}{$\begin{array}{l}\text { FUNCTIONALITY } \\
\text { (Roland-Morris } \\
\text { questionnaire) }\end{array}$} & Pre- & 21 & 10.2 & 10.0 & 2.0 & 23.0 & 5.4 & \multirow{3}{*}{$<0.001$} \\
\hline & Post- & 21 & 4.1 & 1.0 & 0.0 & 20.0 & 5.2 & \\
\hline & $\begin{array}{l}\text { Diff (pre- } \\
\text { post-) }\end{array}$ & 21 & -6.1 & -5.0 & -17.0 & 0.0 & 4.5 & \\
\hline \multirow{3}{*}{$\begin{array}{l}\text { PAIN LEVEL } \\
\text { (Visual Analog } \\
\text { Scale of Pain) }\end{array}$} & Pre- & 21 & 4.8 & 5.0 & 0.5 & 9.0 & 2.1 & \multirow{3}{*}{$<0.001$} \\
\hline & Post- & 21 & 1.7 & 2.0 & 0.0 & 5.0 & 1.7 & \\
\hline & $\begin{array}{c}\text { Diff (pre- } \\
\text { post-) }\end{array}$ & 21 & -3.0 & -3.0 & -7.0 & 0.0 & 1.9 & \\
\hline
\end{tabular}

Note: * Pain level: non-parametric Wilcoxon test, $p<0.05$. Other variables: Student's t-test, $p<0.05$.

Source: Research data.

Table 3 - Descriptive statistics of the variables torque peak, work in flexion and extension, F/E ratio, and p values of statistical tests

(To be continued)

\begin{tabular}{lcccccccc}
\hline Variable & Assessment & $\mathbf{N}$ & Mean & Median & Minimum & Maximum & $\begin{array}{l}\text { S } \\
\text { Standard } \\
\text { deviation }\end{array}$ & $\begin{array}{l}\text { value* } \\
\text { (pre- } \mathbf{x} \\
\text { post }^{*} \text { ) }\end{array}$ \\
\hline $\begin{array}{l}\text { Torque Peak } \\
\text { Flexion }\end{array}$ & Pre- & 21 & 133.4 & 138.0 & 58.0 & 229.0 & 48.0 & \\
& $\begin{array}{c}\text { Post- } \\
\text { Diff (pre- } \\
\text { post-) }\end{array}$ & 21 & 147.6 & 142.0 & 66.0 & 236.0 & 53.0 & 0.008 \\
& Pre- & 21 & 14.2 & 9.0 & -19.0 & 72.0 & 22.0 & \\
\hline $\begin{array}{l}\text { Torque Peak } \\
\text { Extension }\end{array}$ & $\begin{array}{c}\text { Post- } \\
\text { Diff (pre- } \\
\text { post-) }\end{array}$ & 21 & 144.0 & 138.0 & 46.0 & 309.0 & 58.1 & $<0.001$ \\
& 21 & 40.1 & 34.0 & -27.0 & 130.0 & 38.8 & \\
\hline
\end{tabular}


Table 3 - Descriptive statistics of the variables torque peak, work in flexion and extension, F/E ratio, and p values of statistical tests

(Conclusion)

\begin{tabular}{lcccccccc}
\hline Variable & Assessment & N & Mean & Median & Minimum & Maximum & $\begin{array}{l}\text { Standard } \\
\text { deviation }\end{array}$ & $\begin{array}{l}\text { value* } \\
\text { (pre- } x \\
\text { post-) }\end{array}$ \\
\hline Work Flexion & Pre- & 21 & 84.3 & 77.0 & 39.0 & 136.0 & 30.7 & \\
& Post- & 21 & 98.2 & 96.0 & 43.0 & 161.0 & 34.2 & 0.001 \\
& $\begin{array}{c}\text { Diff (pre- } \\
\text { post-) }\end{array}$ & 21 & 13.9 & 10.0 & -8.0 & 65.0 & 16.6 & \\
\hline \multirow{2}{*}{ Work Extension } & Pre- & 21 & 64.0 & 61.0 & 8.0 & 178.0 & 40.0 & \\
& Post- & 21 & 90.7 & 89.0 & 27.0 & 203.0 & 38.5 & $<0.001$ \\
& $\begin{array}{c}\text { Diff (pre- } \\
\text {-post-) }\end{array}$ & 21 & 26.7 & 21.0 & -18.0 & 81.0 & 26.3 & \\
\hline F/E Ratio & Pre- & 21 & 169.1 & 136.0 & 69.0 & 800.0 & 152.0 & \\
& Post- & 21 & 107.4 & 110.0 & 65.0 & 185.0 & 27.9 & 0.001 \\
& Diff (pre- & 21 & -61.8 & -21.0 & -678.0 & 18.0 & 145.8 & \\
\hline
\end{tabular}

Note: * F/E ratio: non-parametric Wilcoxon test, $p<0.05$. Other variables: Student's t-test, $p<0.05$.

Source: Research data.

The sample loss of 10 subjects after the $3^{\text {rd }}$ session may be attributed to the difficulty in assimilating and performing the protocol and relying on prospective outcomes. The 5 subjects who quit after the $4^{\text {th }}$ week may have done so because of pain reduction from the first sessions, allowing the subject to resume his daily activities without worrying about the consolidation of outcomes. These findings show that short-term protocols are less vulnerable to sample loss, but more vulnerable to keep lumbar and pelvic stability.

The fact that the protocol has not generated a significant increase in mobility of the lumbar segment may be attributed to the better muscle control, providing the increased passive stiffness required to promote stability.

The protocol of this study has some similarities with the currently used protocols, such as focus on motor control exercises, however, at the same time, it shows a concern with the muscle group of trunk extensors recruiting both on an isometric and isotonic basis, since we realized the weakness of this grouping through the isokinetic test. Non-systematic description of the treatment protocols adopted in the studies surveyed makes it difficult to replicate and compare them to other protocols, hindering a deeper discussion.

The outcomes were positive with regard to strength gain and balance of the trunk flexor and extensor muscles. There was a reduced pain level and an improved functionality, with increased flexibility in the posterior chain muscles, without significantly increasing the lumbar segment mobility.

The study also showed interdependence between pain and functionality, corroborating most scientific evidence available in the literature.

It may be regarded as a research limitation poor adherence to the program. Among the reasons for this, there is the difficulty in raising awareness of the importance of treatment, assimilation of the correct technique to perform the exercises proposed in the protocol and, also, lack of time to perform them. These reasons refer us to the need for greater investment in health communication, since assertiveness and empathy are important components for establishing the therapeutic bond required for adherence to any treatment program.

There is a need for incorporating practices to raise awareness based on the health education framework, 
in order to promote greater adherence among participants especially in the acute phase, where sample losses are usually due to difficulties in understanding and assimilating relevant information related to the protocol adopted.

\section{References}

1. Hodges PW. Is there a role for tranversus abdominis in lumbo-pelvic stability? Man Ther. 1999;4(2):74-86.

2. Panjabi MM. Clinical spinal instability and low back pain. J Electromyogr Kinesiol. 2003;13(4):371-9.

3. Aquino CF, Viana SO, Fonseca ST, Bricio RS, Vaz DV. Mecanismos neuromusculares de controle da estabilidade articular. R Bras Ci e Mov. 2004;12(2):35-42.

4. Reinehr FB, Carpes FP, Mota CB. Influencia do treinamento de estabilização central sobre a dor e estabilidade lombar. Fisioter Mov. 2008;21(1)123-9.

5. Hodges PW, Richardson CA. Feedforward contraction of transversus abdominis is not influenced by the direction of arm movement. Exp Brain Res. 1997; 114(2):362-70.

6. Richardson C, Hodges PW, Hides J. Therapeutic exercise for spinal segmental stabilization in low back pain: scientific basis and clinical approach. Edinburgh: Churchill Livingstone; 1999.

7. Hides JA, Jull GA, Richardson CA. Long-term effects of specific stabilizing exercises for first-episode low back pain. Spine. 2001;26(11):E243-8.

8. Akuthoda V, Nadler SF. Core strengthening. Arch Phys Med Rehabil. 2004;85(3):S86-92.

9. Keller A, Johansen JG, Hellesnes J, Brox JI. Predictors of isokinetic back muscle strength in patients with low back pain. Spine. 1999;24(3):275-80.

10. Henry SM, Teyhen DS. Ultrasound imaging as a feedback tool in the rehabilitation of trunk muscle dysfunction for people with low back pain. J Orthop Sports Phys Ther. 2007;37(10):627-34.

11. Endleman I, Critchley DJ. Transversus abdominis and obliquus internus activity during pilates exercises: measurement with ultrasound scanning. Arch Phys Med Rehabil. 2008;89(11):2205-12.
12. Costa LO, Maher CG, Latimer J, Smeets RJ. Reproducibility of rehabilitative ultrasound imaging for the measurement of abdominal muscle activity: a systematic review. Phys Ther. 2009;89(8):756-69.

13. Silva MAC, Dias JM, Silva MF, Mazuquin BF, Abrão T, Cardoso JR. Análise comparativa da atividade elétrica do músculo multífido durante exercícios do Pilates, série de Williams e Spine Stabilization. Fisioter Mov. 2013;26(1):87-94.

14. Delitto A, Rose SJ, Crandell CE, Strube MJ. Reliability of isokinetic measurements of trunk muscle performance. Spine. 1991;16(7)800-3.

15. Yahia A, Ghroubi S, Kharrat O, Jribi S, Elleuch M, Elleuch MH. A study of isokinetic trunk and knee muscle strength in patients with chronic sciatica. Ann Phys Rehabil Med. 2010;53(4):239-9.

16. Schober P. The lumbar vertebral column and backache. Munch Med Wschr. 1937;84:336.

17. Torres TM, Ciconelli RM. Instrumentos de avaliação em espondilite anquilosante. Rev Bras Reumatol. 2006;46(Supl. 1):52-9.

18. Rosen E, Fetto J, Gross J. Exame musculoesquelético. Porto Alegre: Artmed; 2000.

19. Melo SV, Linhares LD, De Almeida RD. Efeito do método Samiball ${ }^{\circledR}$ na flexibilidade e expansibilidade em vítima de queimadura: relato de caso. Rev Bras Queimaduras. 2011;10(2):71-4.

20. Nusbaum L, Natour J, Ferraz MB, Goldenberg J. Translation, adaptation and validation of the Roland-Morris questionnaire - Brazil Roland-Morris. Braz J Med Biol Res. 2001;43(2):203-10.

21. Agne JE. Eletrotermoterapia: teoria e prática. Santa Maria: Orium; 2005.

22. Kolyniak IEG, Cavalcanti SMB, Aoki MS. Avaliação isocinética da musculatura envolvida na flexão e extensão do tronco: efeito do método Pilates ${ }^{\circledR}$. Rev Bras Med Esporte. 2004;10(6):487-90.

23. Cruz-Medina E, León-Hernández SR, ArellanoHernández A, Martínez-Gonzaga E, García-Guerrero E, Coronado-Zarco R. Evaluación isocinética y estado funcional en pacientes posoperados por hernia de disco lumbar. Cir Ciruj. 2008;76(5):373-80. 
24. Silva Neto M, Simões R, Grangeiro Neto JA, Cardone CP. Avaliação isocinética da força muscular em atletas profissionais de futebol feminino. Rev Bras Med Esporte. 2010;16(1):33-5.

25. Secchi LLB, Muratt MD, Andrade NVS, Greve JMD’A. Dinamometria isocinética de tronco em nadadores de diferentes estilos. Acta Ortop Bras. 2010;18(5):295-7.

26. De Freitas CD, Greve JMD'A. Estudo comparativo entre exercícios com dinamômetro isocinético e bola terapêutica na lombalgia crônica de origem mecânica. Fisioter Pesqui. 2008;15(4):380-6.

27. Gutiérrez LD, Gómez UA, Soto VG. Evaluación funcional e isocinética en pacientes com lumbalgia mecanopostural. Rev Mex Med Fis Rehab. 2006;18(2):55-60.

28. Lee JH, Hoshino Y, Nakamura K, Kariya Y, Saita K, Ito K. Trunk muscle weakness as a risk factor for low back pain: a 5-year prospective study. Spine. 1999; 24(1):54-7.

29. França, FJR, Burke, TN, Claret DC, Marques AP. Estabilização segmentar da coluna lombar nas lombalgias: uma revisão bibliográfica e um programa de exercícios. Fisioter Pesqui. 2008;15(2):200-6.

30. Koumantakis OCA, Watson PJ, Oldhan JA. Trunk muscle stabilization training plus general exercise versus general exercise only: randomized controlled trial of patients with recurrent low back pain. Phys Ther. 2005;85(3):209-25.
31. Pereira NT, Ferreira LAB, Pereira WM. Efetividade de exercícios de estabilização segmentar sobre a dor lombar crônica mecânico-postural. Fisioter Mov. 2010;23(4):605-14.

32. Oliveira TH, Melo RM, Leite MRR, Valadas $M$, Venturini C, Nascimento MR, et al. Avaliação de dor e desempenho funcional em pacientes com dor lombar crônica inespecífica: Follow-up 2 e 5 meses. Ter Man. 2008;6(28):333-9.

33. Hides JA, Richardson CA, Jull GA. Multifidus muscle recovery is not automatic after resolution of acute, firstepisode low back pain. Spine. 1996;21(23):2763-9.

Received: 04/12/2013

Recebido: 12/04/2013

Approved: 11/09/2013 Aprovado: 09/11/2013 